\title{
Transzneműség és a nemi identitás interakciója
}

\section{Főglein Karola}

ELTE Pedagógiai és Pszichológiai Kar, Szexuálpszichológiai szakpszichológus képzés

\begin{abstract}
A transznemüség témaköre napjainkban egyre elfogadottabb és egyre jobban kutatott terület. A fellelhető szakirodalom minősége, kutatási módszerei, elemzési szempontjai rendkívül változatosak. A transznemüséget a legtöbb kutatás az LMBTQ (leszbikus, meleg, biszexuális, transznemü, queer) ernyőfogalom alatt vizsgálja. Munkám célja, hogy a transznemüség témáját minél több szempontból mutassam be. Vizsgálom többek között a csoport heterogenitását, a transznemü identitás lehetséges fejlődését leíró modelleket, terápiás segítségnyújtás lehetséges útjait, valamint a transznemüek helyzetét az egészségügyben és az oktatás területén. A transznemü identitásfejlődés az egyén szintjén túl számos elméleti, társadalmi, kutatás-módszertani kérdést is felvet. Munkámban az egyéni fejlődési szempontot igyekszem szem előtt tartani, részletesebben tárgyalni, természetesen utalva a kapcsolódó területekre is.
\end{abstract}

Kulcsszavak: transznemüség, identitás, terápia, oktatás, fejlődés

A transznemüség témaköre kevéssé ismert, ám napjainkban egyre divatosabb terület. Az internet, így az információk gyors és széleskörü terjedésével az érintettek egyre hamarabb képesek felismerni nemiidentitás-problémájukat, könnyebben találnak elfogadásra és támogatásra. A társadalom a változásokat kevésbé gyorsan követi, így a transznemü személyek világszerte továbbra is küzdenek a diszkrimináció, az érdekés jogérvényesítés, a hivatalos nemváltoztatás és az orvosi ellátás nehézségeivel.

A továbbiakban szeretnék néhány olyan tanulmányt, kutatási eredményt ismertetni, amely hozzájárulhat a transzneműség minél szélesebb körü és minél több szempontú megismeréséhez és a transznemủ identitás kialakulásának megértéséhez. Szeretnék támpontokkal szolgálni a transznemü emberek segítéséhez mind pszichológiai, mind pedagógiai területeken.

\section{Meghatározás}

\section{Nem}

Az ember neme Szilágyi (é.n.) nyomán hétféleképp határozható meg:

1. kromoszomális nem: milyen kromoszómákat tartalmaznak a test sejtjei (általában $X X$ vagy $X Y$ )

2. gonadális nem: az egyén petefészkekkel vagy herékkel rendelkezik-e

3. hormonális nem: melyik nemi hormonok vannak túlsúlyban a személy testében (ösztrogén vagy tesztoszteron)

4. belső nemi szervek: a személy petefészkekkel, méhhel, hüvellyel, vagy ondóvezetékekkel, ondóhólyaggal, prosztatával rendelkezik-e

5. külső nemi szervek: a személynek csiklója, nagy- és kis szeméremajkai, vagy pénisze és herezacskója van-e

6. tanult nem: lányként vagy fiúként nevelik-e a gyermeket

7. szexuális identifikáció: a személy milyen nemúnek tartja magát

A fent felsorolt pontok összefüggenek, de nem következik egyenesen egyik a másikból; mindenhol lehetnek eltérések, kivételek. 
Általános esetben, a legtöbb embernél ezen tényezők mindegyike egyfelé mutat, és csak betegség, fizikai eltérések esetén vizsgálják őket külön.

Születéskor- vagy az ultrahangos vizsgálatoknak köszönhetően még magzati korban- az orvos a csecsemő nemét a külső nemi szervek alapján ítéli meg, és innentől kezdve a gyerekre ilyen nemüként is tekintenek, ez alapján nevelik.

A tanult nem általában abból következik, hogy a gyermekre milyen nemi sztereotípiák alapján reagál a környezete. Ennek eredményeképpen sajátítja el a gyerek a nemi szerepeket. A tanult nemhez kapcsolódó fogalom a társadalmi nem, vagy angol kifejezéssel gender. A társadalmi nem azt fejezi ki, hogy a társadalom az egyén neméről mit gondol, mit társít hozzá.

Transznemű személyek esetében a születéskor külső nemi szervek alapján meghatározott nem nem egyezik a személy szexuális identifikációjával.

\section{Transz*}

Aki a transznemüség témájában kutatásokat kezd el keresni, rögtön szembe találja magát azzal a problémával, hogy mit is nevezünk transz* identitásnak. Ahány cikk, annyiféle meghatározás létezik a fogalomra, módszertantól és mintavételtől függően. $A$ Transvanilla Transznemű Egyesület honlapján olvasható meghatározás szerint: „Transz emberek: Az emberek különféle, széles rétegét lefedő kifejezés azokra, akik nemi identitása vagy nemének kifejezése nem egyezik meg teljesen azzal, ahogyan születésükkor meghatározták azt. Ebbe a körbe tartoznak azok (de nem csak azok!), akik transzszexuális emberként, transznemű emberként, transzvesztitaként/ cross-dresser emberként, nem-binárisként, dzsender variáns emberként stb. határozzák meg magukat. Akik nem transz* emberek, azok a ciszneműek. Tehát ez alatt értünk mindenkit, akiknek a születésekor meghatározott nemével megegyezik a nemi identitása, biológiai neme és a nemének kifejezése." (http://transvanilla.hu/szotar, 2016).

A transznemű egyén „klasszikus”, szűkebb értelemben olyan ember, akinek születéskor neki tulajdonított neme nem egyezik meg az önmaga által definiált nemmel. Ennek megfelelően transznő az az egyén, akit férfiként anyakönyveztek, viszont nőként tekint magára. Transzférfi az az egyén, akit nőként anyakönyveztek, viszont férfiként tekint magára.

Ez a meghatározás a kategóriaalapú, dichotóm gondolkodásmódon belül marad. Ezek szerint az ember vagy férfi, vagy nő. Gagné, Tewksbury és McGaughey (1997) mintájában a transznemű emberek többsége egyetért ezzel a gondolatmenettel, és kifejezetten a másik nemhez szeretnének tartozni. Ezzel szemben a transz ${ }^{*}$ csoport tagjai néha azért vállalják csoporttagságukat, hogy ezt a gondolatrendszert megszüntessék, vagy legalább hiányosságaira felhívják a figyelmet (Gagné és mtsai, 1997). Coming outjuk ${ }^{1}$ ebből a szempontból társadalmi felhívásnak minősíthető. A queerelmélet és -mozgalom igyekszik társadalmi szinten ezt a nézőpontot képviselni, így ebben a tekintetben a transznemüek és a queerek csoportja hasonló. A queer szó eredeti jelentése negatív értelemben vett furcsa, bizarr, különc. A queerelmélet egyfajta szemléletmód, amely elutasít mindenféle kategóriaalapú, éles kategóriahatárokat feltételező, dichotóm megközelítést, leginkább a nemi identitás, társadalmi nem és a nemi szerepek kérdéskörében. A queerelmélet azt a

\footnotetext{
1 Coming out: előbújás. Az a folyamat vagy esemény, melynek következményeképp a személy önmaga és mások előtt nyíltan felvállalja nemi identitását vagy szexuális orientációját. A coming out nem általános érvényü: a személy maga dönti el, hogy kiknek és mikor bújik elő.
} 
nézőpontot kérdőjelezi meg, amely a biológiai nem, a társadalmi nem, és a szexuális vágy között stabil és koherens kapcsolatot feltételez (Jagose, 2003). A queercsoport rendkívül heterogén, szinte bárki ide tartozhat, aki nem fér bele a „hagyományos”, heteroszexuális identitást, illetve női/ férfi nemi identitást feltételező keretrendszerbe. A queer a kategórián kívüli, „egyéb” kategória. A queer-mozgalom kialakulásának történetét Annamarie Jagose vezeti végig Bevezetés a queer-elméletbe című munkájában (2003).

Érdekes kérdés, hogy fordított esetben is transzneműnek kategorizálható-e az egyén? Erre David Reimer lehet példa, akit orvosi műhiba miatt szülei lányként neveltek fel, serdülőkorától kezdve viszont mégis eredeti nemének megfelelően, férfiként szeretett volna élni. Ebben az esetben tehát nem a születési nem tért el a vágyott nemtől, hanem a társadalmi nem, amely itt az identitásalakulás alapját adta (lányként nevelték). Az esetből As Nature Made Him: The Boy Who Was Raised As A Girl címmel John Colapinto írt könyvet, amely 2000-ben jelent meg.

A transznemüség előfordulási gyakoriságát illetően megoszlanak a vélemények. Cohen-Kettenis és Gooren (1999) összefoglalója szerint a vizsgálatok nagyjából 1:30 000 és 1:100 000 közé becsülik a transzneműek arányát, Lev (2004) 1:9 000 és 1:100 000 közti adatot említ. A legújabb összefoglaló cikk szerint (Collin, Reisner, Tangpricha és Goodman, 2016) a transznemüség gyakorisága erősen függ a fogalom definíciójától, valamint a vizsgálati feltételektöl (mintavétel, módszer). Collin és munkatársai (2016) alapján a transznemüség prevalenciája 95\%-os konfidencia-intervallummal 9,2:100 $000(95 \% \mathrm{Cl}$ = 4,9-13,6), amennyiben a hormonkezelés és a sebészeti beavatkozások igénybevétele képezi a fogalom meghatározását. Az önbeszámolós kutatások ennél magasabb arányt, 355:100 000 (95\% Cl = 144-566) említenek. A Transvanilla Transznemú Egyesület szerint a transz* identitású emberek aránya 2-4\% között lehet (személyes közlés).

Az alacsony elemszám miatt a kutatások nagyon gyakran heterogén mintával dolgoznak transz* gyűjtőnév alatt, illetve sok cikk együtt kezeli az LMBTQ-identitású személyeket. Ez felveti a kérdést, hogy ilyen heterogén mintából mennyire érvényes következtetések vonhatók le. A másik felvetés, hogy amennyiben az LMBTQ-csoportot egységesen vizsgáljuk, azzal az egyes tagcsoportok (leszbikus, meleg, biszexuális, transz*, queer) jellemzői homogenizálódnak. Ezt alkalmasint maguk a csoporttagok kifogásolják. Ennek ékes példája Fassinger és Arseneau (2007) beszámolója. A szerzőpáros cikkében megkísérli több szempontból (identitásfejlődés, coming out, nemi, szexuális, kulturális orientáció, egészség, társas kapcsolatok, tanulás és munka, jogok) jellemezni külön-külön az LMBT-csoportok tapasztalatait. Müvük felhívja a figyelmet arra, hogy - bár sokszor egy kalap alatt kezeljük az LMBT-embereket -, számottevő különbség van a négy csoport közt. A cikk címe beszédes, egy transznemú kliens szájából elhangzott mondat: „I'd Rather Get Wet Than Be Under That Umbrella” (hozzávetőlegesen: „Inkább megázom, mint hogy az alá az esernyő alá álljak” - utalva ezzel az LMBT kifejezés átfogó, „esernyő” jellegére).

További fontos szempont, amely az LMBTQ-csoportok együttes kezeléséből következhet, hogy a leszbikus, meleg és biszexuális megkülönböztetés szexuális orientáción alapul, így az egyén mások iránt érzett érzelmi, erotikus és kapcsolati preferenciáján múlik, ilyen értelemben a másikról szól. Ezzel szemben a transz* és queerkategória az egyén öndefinícióján, nemi önkifejezésén múlik, nemiorientációalapú, és független attól, hogy az egyén milyen nemü emberek iránt érez erotikus vonzalmat (Fassinger és Arseneau, 2007).

A transznemű csoport heterogenitását példázza Gagné és mtsai (1997) cikke. Ők interjúmódszerrel kizárólag transznemű emberektől nyertek adatokat, a coming out folyamatát, az identitásformálást és a transznemű közösséghez tartozást mérték fel. 
A megkérdezett 65 transznő öndefiníciója alapján a csoport összetétele a következőképpen alakult: 27 preoperatív transzszexuális, 10 posztoperatív transzszexuális, 4 nonoperatív transzszexuális, 2 fetisiszta transzvesztita, 17 (nem fetisitsza) transzvesztita, 5 fő „egyéb”. Ez az 5 fő transzvesztita volt, nem szerettek volna operációt, viszont identitásukat a bináris nő/férfi rendszeren kívül határozták meg, és szándékuk az volt, hogy kategorizáció nélkül, szabadon kifejezhessék nemüket és szexualitásukat. Érdemes az utóbbi 5 ember öndefinícióját részletezni:

- 1 fő radikális nemi határsértő (radical transgenderist): anatómiailag férfi, férfi nemi identitással, aki az átöltözést arra használja, hogy női énjét kifejezhesse. Nem ért egyet a bináris rendszerrel.

- 1 fö „ambigenderist”: nőként és férfiként is él, hangulatától függően, illetve a két nem jellegzetességeit egyszerre viselve. Úgy véli, a szexuális orientáció kategóriája nem létezik, és a szexualitást spektrumként kezeli.

- 3 fő harmadik nemüek: úgy gondolják, mindenkinek van nőies és férfias oldala is, melyeket egyenlően szeretnének megélni és kifejezni, így a két nem kombinációjaként élnek.

\section{A transznemüség pszichiátriai megközelítése}

Mindkét nagy, betegségeket osztályozó rendszerben létezik a transzszexualizmus mint pszichiátriai betegségkategória, először 1980-ban szerepelt a diagnózisok között, a DSM-III-ban (Cohen-Kettenis és Gooren, 1999).

A BNO szerint a transzszexualizmus definíciója (F 64.0) (Takács, 2006):

1. Az a vágy, hogy az ember az ellenkező nem tagjaként élhessen, és így fogadják el. Ezt általában az a vágy kíséri, hogy testét sebészeti beavatkozásokkal és hormonkezeléssel minél jobban összhangba hozza az előnyben részesített nemmel.

2. Transzszexuális identitása legalább két éve folyamatosan fennáll.

3. Ez a rendellenesség nem egy másik mentális zavar vagy kromoszóma-rendellenesség tünete.

A DSM-V. 302. szám alatt definiálja a transzszexualizmust mint „nemi diszfóriát”, különböző életkori csoportokban.

Sokan megkérdőjelezik a transzszexualizmus betegségmivoltát (Gagné és $m t s a i$, 1997; Vanderburgh, 2008). Úgy tủnik, a kategóriának megvan az esélye, hogy hasonló utat járjon be, mint a homoszexualitás ${ }^{2}$.

A transzneműeknek, amennyiben nemi megerősítő mütétet ${ }^{3}$ kívánnak, miután (hazánkban legalábbis) nincs széles körben elismert, hivatalos terápiás protokollja a probléma kezelésének, jelenleg egyetlen esélyük önmaguk vállalására az egészségügyi rendszerben való jelenlét mint „beteg” (Takács, 2006), ennek minden előnyével és hátrányával. A diagnózis - így sok transznemű további élete - nagyban függ az azt végző orvos véleményétől, miután a diagnosztikus kritériumok felmérése szubjektív (Cohen-Kettenis és Gooren, 1999).

\footnotetext{
2 A hírek szerint Dániában tervezik elsőként törölni a transzszexualizmust a mentális betegségek listájáról; azt mondják, nem várnak tovább a WHO döntésére, és 2017. január 1-jével az intézkedés életbe lép (http:// transvanilla.hu/hirek/dania-nem-var-a-who-ra-es-torli-a-transznemuseget-a-mentalis-betegsegek-listajarol, 2016).

3 A mütét elnevezésének változása híven tükrözi a társadalom hozzáállását a kérdéshez, egyre inkább felismerve, hogy a nemi identitás kifejezése belülről fakadó, lelki igény. A szakirodalom többsége még a nemi átalakító műtét fogalmát használja (sex reassignment surgery, SRS), az újabb elnevezések: nemi helyreállító műtét (sex reconstruction surgery), illetve nemi megerősítő mütét (gender confirmation surgery, gender affirmation surgery). Munkámban a nemi megerősítő mủtét elnevezést használom.
} 


\section{Identitásfejlődés}

A transznemüek identitásfejlődésére több szempontból tekinthetünk. Amikor az LMBTQ-csoportot egyben kezeljük, elsőként a lineáris, szakaszokra osztott identitáselméletek juthatnak eszünkbe. Ilyen elmélet pl. Troiden vagy Cass elmélete az 1980as évek környékéröl. Cass (1979) a következő, egymásra épülő szakaszokat különítette el: konfúzió, összehasonlítás, tolerancia, elfogadás, büszkeség, szintézis.

Ezeket az elméleteket elsősorban homoszexuális identitások vizsgálata révén állították fel. Feltételezhetjük, hogy ezen elméletek ugyanannyira lehetnek érvényesek a transznemüekre is, mint a homoszexuálisokra, azonban a teóriák sok esetben nem az identitás kialakulását veszik górcső alá, sokkal inkább a coming out folyamatának modelljei lehetnek (Dillon, Worthington és Moradi, 2011). Ezen modellek alapján úgy tünhet, mintha a személy identitása egyrészt kizárólag a szexuális orientáción múlna, másrészt pedig csak serdülőkortól alakulna ki, holott az egyénnek már csecsemőkorától gyülik a tapasztalata önmagáról és a világban elfoglalt helyéröl, a fiú/lány kategória (vagy kontinuum?) mentén. A gyerekek többsége 2-3 éves korára tud választ adni arra a kérdésre, hogy ő fiú-e vagy lány. A nemi konstancia 6-7 éves korra legtöbbször biztonsággal kialakul (Egan és Perry, 2001). Megjegyzendő, hogy Vanderburgh (2008) szerint, a „másság” érzése a legtöbb transznemú személynél már kora gyermekkorban megjelenik, ugyanakkor a kérdés megítélését nehezíti, hogy akik gyerekként bizonytalanok nemi identitásukat illetően, nagyon kevés gyermekkori emléket őriznek. Cohen-Kettenis és Gooren (1999) szerint a nemi diszfóriában szenvedő gyermekek gyakrabban késnek a nemi identitással kapcsolatos tudás elsajátításával, pl. gyakrabban, és későbbi életkorig keverik a fiú/lány megnevezéseket, és nehezebben válaszolják meg biztonsággal a nemre vonatkozó kérdéseket. Mindemellett a gyermekkori nemi diszfória úgy tűnik, nagyobb kapcsolatban van a későbbi homoszexualitással, mint a transznemüséggel (Cohen-Kettenis és Gooren, 1999). Újabb kutatások szerint (Cohen-Kettenis és Pfäfflin, 2003, idézi Lev, 2010) a súlyosabb fokú nemi diszfória gyermekkorban erősebb korrelációt mutat a felnőttkori transzszexualizmussal.

A coming out mind a leszbikus, meleg és biszexuális, mind a transz* ${ }^{*}$ csoport identitásának vállalásában, az egyén életébe való integrálásában nagy szerepet játszik. Sőt, egy transznemü egyén, amennyiben vállalni szeretné önmagát, talán még jobban ki van téve a csoporttagságával járó stigmatizációnak, mivel feltűnőbb, hogy a társadalom atipikus tagja. Aki nemi megerősítő mütétre vállalkozik, mindenképp rá van kényszerülve, hogy felvállalja transznemüségét. A mütét után új identitás kialakítása szükséges, immár, mint férfi vagy nő (a transznemü öndefiníció helyett). Gagné és $m$ tsai (1997) kutatási eredményei szerint a mütéten átesettek többsége el is hagyja a támogató hátországot, a transz* közösséget.

Az univerzális identitásfejlődési elméletek, bár sokszor szintén a szexuális orientációból indulnak ki és heteronormatív szemléletüek, szintén érvényesek lehetnek a transznemű emberekre. Ezek az elméletek a nemi identitást hajlamosabbak úgy kezelni, mint az identitás egy részterületét. Ebböl a nézőpontból a transzneműség integrációja az egyén önmagáról alkotott képébe könnyebben kivitelezhetőnek tünik, illetve a személy nem látszik annyira sérülékenynek. Dillon és mtsai (2011) szerint a szexuális identitás fejlődése több párhuzamos folyamatból áll: explorálatlan elköteleződés a heteroszexualitás mellett, aktív exploráció, diffúzió, elmélyülés és elköteleződés, szintézis. Megkülönböztetik továbbá az egyéni és a társas szintet. Ezen dimenziók mentén a személy eltérő pozícióban lehet identitását (és annak felvállalását) tekintve. A modell újdonsága a lineáris elméletekhez képest, hogy eszerint az egyén státusza élete során változhat, egy-egy státusz visszatérhet az egyén tapasztalatai alapján, újravizsgálhatja öndefinícióját. 
A nemi identitás többdimenziós modelljét nyújtja Egan és Perry (2001) cikke. A szerzők a nemi identitás összetevőit igyekeztek leírni, 4-8. osztályos gyermekek kérdőíves adatai alapján. Eredményeik szerint a nemi identitás a következő dimenziókból áll: 1. az érzés, hogy az egyén kompatibilis a nemével (a kategória tipikus tagja, elégedett biológiai nemével), 2. érzékelt nyomás a szülök, barátok felöl, és megfelelési igény, hogy az egyén teljesítse a nemi sztereotípiákat, 3. saját nem preferenciája (az egyén nemi csoportja a másik felett van). A dimenziók egymástól viszonylag függetlenek, de mind kapcsolatban állnak a pszichoszociális alkalmazkodással. Ez a kutatás tulajdonképpen alátámasztja, hogy a nemi identitás társas konstrukció, az öndefiníció „másokhoz képest” jön létre.

\section{Terápiás segítség}

\section{Differenciáldiagnosztika}

A terápiás segítségnyújtás általában a diagnózis felállításával indul, ami meghatározza a terápiás kereteket is.

A diagnosztika kapcsán Vanderburgh (2008) hívja fel a figyelmet a differenciáldiagnózis fontosságára, illetve a diagnózis szubjektív mivoltára. Nézete szerint a családot alaposan fel kell mérni, amennyiben úgy gondolják, gyermekük transznemü lehet, hiszen a nemi szerepviselkedés, illetve az ellenkező nemre jellemző tevékenységek engedélyezése minden családban más-más mértékben elfogadott. Lényeges a család diszfunkcionális müködésének, az esetleges abúzusnak a feltárása. Lehet, hogy a gyerek azért viselkedik másként, mint ami nemének megfelelő lenne, mert a) szeretné kielégíteni szülei vágyát, akik más nemü gyerekre vágytak, ezáltal elismerést szeretne kapni, vagy mert b) abúzus esetén menekülő stratégia lehet a gyermek azon vágya, hogy valaki más legyen.

Nagyon érdekes, hogy a szerző Atwood (2007, idézi Vanderburgh, 2008) nyomán az Asperger-szindrómától javasolja elkülöníteni a nemiidentitás-problémát. Meglátása szerint az aspergeres gyermekek azért szeretnének mások lenni, mert könnyebben szeretnének barátokat szerezni. Mivel a kapcsolatteremtés képessége női attribútum, az aspergeres fiúgyermek esetleg emiatt szeretne lánnyá válni. Az Aspergerszindrómás fiúk megfigyelhetik, hogy a környezetükben levő lányok, nők mennyivel könnyebben teremtenek kapcsolatot másokkal, milyen női szerepek segítik ezt. A sikeres barátkozáshoz vezető (lányosnak ítélt) viselkedést próbálhatják utánozni, ami felvetheti a transznemúség problémáját. A differenciáldiagnózis azért fontos, mert az Asperger-szindróma gyakorisága jóval nagyobb (1:250) mint a transznemúségé.

Lev (2010) szerint a nemi diszfóriás, illetve a nemi szerepviselkedésnek nem megfelelő (gender role nonconforming) gyerekek megkülönböztetése fontos, utóbbi esetben ugyanis kevesebb az esélye a későbbi nemiidentitás-problémáknak, mivel azok nem járnak szenvedéssel, distresszel.

\section{Terápiás megközelítések}

Mivel a transzszexualizmus jelenleg szerepel a betegségek listáján, így könnyű elcsúszni a konverziós (az identitás megváltoztatását célzó) terápiás irányba. A konverziós terápia ötlete abból az időből származik, amikor a homoszexualitást még betegségként tartották számon. Lényege, hogy a személyt megpróbálják „meggyógyítani”, születési nemének megfelelő viselkedés irányába terelni, megtanítják „tipikus, normális” (heteroszexuális) nőnek vagy férfinek lenni. Ma is vannak, akik ezt támogatják, bár a kutatások 
nem támasztják alá e terápia hasznosságát, kártékonyságát viszont igen (Vanderburgh, 2008). A beszámolók szerint a transznemű személyek a konverziós terápia kapcsán legfeljebb azt tanulják meg, hogyan nyomják el még jobban önmagukat, jelentős distresszt és bűntudatot okozva ezzel maguknak, növelve a depresszió, valamint az öngyilkosság kockázatát. A sikertelen terápia eredményeként kialakul a terápiákkal szembeni általános averzió, ami növeli a sérülékenység kockázatát. Konverziós terápiára a transznemü személyek általában családi nyomásra, gyermek- vagy serdülőkorban jutnak el.

Jelenleg az affirmatív terápiás irányzat elterjedtebb, mely az elfogadást, az egyén lelki és szociális szükségleteinek támogatását hangsúlyozza. Ez történhet a család bevonásával, vagy egyéni terápiás keretben. A családdal való munka szintén változatos, hiszen nem mindegy, hogy a szülő transznemủ-e vagy a gyermeke.

Családterápiás környezetben transznemü terapeutaként dolgozva Vanderburgh (2008) szolgáltat hasznos gyakorlati információkat. Szerinte a legjobb hozzáállás, ha a gyermeket támogatjuk önmaga kifejezésében, bármi legyen is az. Fontos, hogy a szülő is kapjon segítséget gyermeke elfogadásához, saját nézetei, előítéletei, normái felismeréséhez és átalakításához. Ehhez elengedhetetlen az edukáció, megfelelő információk nyújtása, a téves hiedelmek leépítése, bármilyen terápiáról van is szó. Minden érintettet fel kell világosítani az egyéb terápiás lehetőségekről (például orvosi beavatkozások a későbbiekben), valamint arról, mit is jelent pontosan a transznemúség (nem szexuális orientáció!).

Lev (2010) beszámolója csavar még egyet a családi megközelítésen: egy leszbikus pár esetét írja le, akik 5 éves kisfiuk „furcsa” viselkedése miatt kerestek családterápiás segítséget. A pár 3 gyermeket nevelt, még egy fiút és egy lányt, mindketten idősebbek, és biológiai nemüknek megfelelően viselkedtek. A gyerekek biológiai anyja a pár egyik tagja, mesterséges megtermékenyítéssel fogantak meg. A pár másik tagja örökbe fogadta a gyerekeket.

A szülők minden gyermeküket igyekeztek elfogadóan, nemi szerepelvárásoktól mentesen nevelni, nem korlátozták őket a barát-, játék- vagy öltözködésválasztásban. A nemi diszfóriás fiú viselkedése még őket is megdöbbentette: az óvodában kizárólag lányokkal szeretett babázni és hercegnőset játszani, a fiús tevékenységek egyáltalán nem érdekelték. A fiú, amióta csak vannak emlékei, mindig lányként gondolt magára, és az őt ért gúnyolódások ellenére kérte szüleit, hogy hadd lehessen hosszú copfja, vágják le a péniszét, és szólítsák lánynéven. Utóbbi két kérésen a szülők igencsak meglepődtek, ekkor fordultak terapeutához. A helyzet sürgőssé is vált, mivel a kisfiú abban az évben kezdte az iskolát. A szülők nem tudták, hogyan fogadná furcsa fiukat az intézmény, és mit kellene tenniük ezzel kapcsolatban, valamint, hogy engedjenek-e fiuk kérésének, és lányként tekintsenek-e rá. Felmerült egy krízishelyzet is: a fiút 8 éves nővére kapta rajta, amint saját péniszét ollóval igyekezett volna eltávolítani, és sírva kérte anyját, hogy ne akarják rákényszeríteni, hogy fiúként kelljen iskolába mennie. Végül az iskolával egyeztetve a gyermek lánynéven, lányként kezdte meg tanulmányait.

Az eset kapcsán Lev sok tényezőt figyelembe vesz, amelyek kihatnak egy LMBTQ-személy/család terápiájára:

Gyermekvállalási lehetőségek, családszerkezet: az örökbefogadás LMBTQszülők számára igen nehézkes, így legtöbben a mesterséges megtermékenyítést választják. Coming outjuk előtt sokan heteroszexuális kapcsolatban élve válnak szülővé. A kutatások alapján az LMBTQ személyek hajlamosabbak kisebbségi vagy hátrányos helyzetű csoportokba tartozó gyermekeket örökbe fogadni. Vannak, akik más LMBTQpárokkal fognak össze, és természetes úton nemzenek gyermeket. Ilyenkor jogi kérdések is felbukkanhatnak - kié a gyerek, melyik szülőpárnál helyezzék el, hogyan oldják meg a láthatást? 
A transznemű személyeknek azt szokták javasolni, hogy mütétjük előtt vállaljanak gyermeket, vagy fagyasztassák le ivarsejtjüket későbbi felhasználás céljára. Így nekik is születhet vér szerinti gyermekük. A transznemủ személyek szülőségével kapcsolatos ellenvélemény általában az, hogy mivel saját nemük vitatott, gyermekeik sem látnak egyértelmű női/férfi mintákat otthon, ezért ők összezavarodhatnak nemi identitásukat illetően. Az ezzel kapcsolatos kutatások cáfolják ezt a feltevést, és azt mutatják, hogy a transznemü szülők gyermekei általában támogatóak szüleik nemváltásával kapcsolatban.

Gyermeknevelés: a kutatások szerint az LMBTQ családokban általában lazábbak a nemi szerepet illető elvárások a gyermek felé, viszont sokan magától értetődően heteronormatív módon nevelik gyerekeiket. Ugyanakkor a szülőkre nagy társadalmi nyomás nehezedik; bizonyítaniuk kell, hogy joguk van családként élni, „normálisak”, és képesek (heteroszexuális) gyermekeket nevelni. Felmerül a túlvédés és korlátozás kérdése, amikor az észlelt megfelelési kényszer, illetve a szülök saját rossz tapasztalatai miatt túl „tipikus” lányt vagy fiút szeretne nevelni a pár. A gyermek is nehézségekbe ütközhet „mássága” (atipikus családja) miatt, elsősorban az oktatási intézményekben. A legtöbb gyermek a kezdeti nehézségekből, vagy szülei példájából tanulva megtanulja, hogy hol és mennyit érdemes elárulni a családjáról (Béres-Deák, 2010).

Önvád, büntudat: a szülők általában magukat hibáztatják gyermekük szokatlan viselkedése miatt, úgy gondolják, valahol elrontották a nevelést. Ez fokozottan megjelenik az LMBTQ-identitású szülőknél, akikre jelentős társadalmi nyomás nehezedik (lásd feljebb). Identitásuk felvállalása az LMBTQ-szülők LMBTQ-gyermekeinek különösen nehéz lehet, hiszen a coming outtal járó feszültség mellett úgy élhetik meg, szüleiknek csalódást okoznak.

Az egyéni affirmatív terápia elsősorban serdülö- vagy felnőttkorban jöhet szóba. Foglalkozhatunk kizárólag a pszichés problémákkal és azok kezelésével (pl. coming outra felkészülés, ennek feldolgozása akár a családdal együtt; krízisintervenció öngyilkossági késztetés esetén), kizárólag az orvosi beavatkozással (pszichiátriai szakvélemény, hormonkezelés, megerősítő műtét, rehabilitáció), vagy a kettő integrációjával (pszichológiai kísérés az orvosi procedúra előtt-alatt-után). Fontos, hogy a személy már a mütétet megelőzően is szerezzen tapasztalatot a vágyott nembeli életről szerepjáték, vagy éles helyzetben való tesztelés segítségével. Egyes készségek taníthatók, ilyenkor beszédterápia, viselkedésterápia (pl. járás, sminkelés, öltözködés, gesztusok, párkeresési praktikák) is szóba jöhet (Cohen-Kettenis és Gooren, 1999). Fontos az edukáció szerepe: a kliens tudjon a lehetőségeiről, döntéseinek várható pszichés, fizikai, jogi, anyagi következményeiröl.

A hazai egészségügyi és adminisztratív gyakorlatról Takács (2006) ad alapos szociológiai szempontú áttekintést az érintettek nézőpontjából. A szerző interjútechnikával járt utána a hazai gyakorlatnak a nemi megerősítő mütéteket illetően; transzszexuális személyek meséltek tapasztalataikról a magyar egészségügyi és egyéb, a nemváltáshoz szükséges hivatalos procedúrákkal kapcsolatban. A kép lehangoló. Hivatalos protokoll hiányában szinte egy intézménynek sincs bevált gyakorlata, sok esetben egymást feltételező eljárások szükségesek, melyeket ráadásul következetlenül alkalmaznak. Nem egyszer kerülőutas megoldások születtek. A teljes átváltozás évekig is tarthat. Az érintettek komoly fizikai és lelki megpróbáltatásoknak néznek elébe. A (vélt) boldogsághoz vezető út stigmatizációval, megszégyenítéssel, csúszópénzekkel, kiszolgáltatottsággal van kikövezve.

\section{Transznemúség az oktatásban}

A transznemúség jelenlétét az oktatásban Mészáros (2011) és Takács (2007) munkái alapján mutatom be. Ezek a kutatások az LMBT-csoportokat együttesen kezelték, 
mindkettő kvalitatív módszerekkel dolgozott (fókuszcsoport, illetve kérdőívek nyitott kérdésekkel). Az eredmények azt mutatják, hogy az LMBT-személyek többsége tapasztal az oktatási intézményekben diszkriminációt, fizikai és/vagy verbális agressziót, ami jelentős stresszt okoz (ehhez elég akár csak a tudat, hogy a személy bármikor támadásnak lehet kitéve identitása miatt).

Takács (2007) eredményei szerint a kirekesztés, hátrányos megkülönböztetés mintázatai Európa-szerte nagyon hasonlóak. A fiatal LMBT-megkérdezettek „61,2\%-a számolt be negatív iskolai tapasztalatokról". Ez jelenti egyrészt a fizikai/verbális bántalmazást, illetve a tananyag előítéletes, vagy pontatlan, sztereotípiákat fenntartó tartalmát is. A diszkrimináció a fiúkat és a lányokat közel egyenlő arányban érte (61, illetve 58\%). Gyakori volt a gúnyolódás, a kiközösítés. Az érintettek nehezen kértek segítséget; úgy gondolták, mindenképp vállalniuk kellene az előbújást, nem értenék meg őket a tanárok, sőt, volt, aki úgy érezte, az iskolai dolgozók osztják az előítéletes hozzáállást. A tanárok támogató, elfogadó hozzáállásáról csak azon válaszadók 4\%-a számolt be, akik nem rendelkeztek negatív tapasztalatokkal (Takács, 2007).

A személlyel szembeni előítéletes viselkedés sokszor már akkor megnyilvánult, amikor a személy még nem is tudta- értette pontosan, miben más ő, mint a többiek. A tipikus válasz a támadásokra az elviselés, eltitkolás, visszahúzódás, szélsőséges esetben iskolaváltás, vagy a tanulmányok megszakítása volt. Ez, különösen serdülökorban, amikor nyitni kellene a világ felé, rányomhatja a bélyegét a személy későbbi szocializációjára, életbeli lehetőségeire.

A transznemű diákoknak már az oktatási rendszerbe kerüléskor lehetnek gyakorlati problémáik (pl. melyik illemhelyiségbe, öltözőbe menjenek), amiket - amint erre Lev (2010) is rámutat - célszerü a pedagógusokkal karöltve megoldani, tisztázni.

Mészáros (2011) és Takács (2007) írásában is felmerült a diákok részéröl az igény, hogy a pedagógusok értőbben, segítőkészebben viszonyuljanak az LMBTszemélyekhez, esetleg az LMBT-tanárok vállalják nyíltan önmagukat, így nyújtva pozitív modellt az érintett diákoknak. Jelenleg magyar és európai közegben is rendkívül nehéznek tủnik, hogy egy tanár nyíltan vállalja LMBT-csoporttagságát. Mészáros (2011) fókuszcsoportos vizsgálata alapján a hozzáértés igénye a pedagógusokban is megvan, ők úgy gondolják, nem elég kompetensek az LMBT-témák kezelésében; nem tudják, hogyan hozzák szóba a témát, milyen szavakat használjanak, hogyan kezeljék az elöítéletes viselkedést, és sokszor önmaguk attitüdjét sem ismerik.

A tananyaggal kapcsolatos kifogás leginkább az volt, hogy heretonormatív gondolkodást közvetít, sokszor szó sem esik az LMBT-identitásokról, pedig, ha szóba kerülne a téma, az szélesíthetné a diákok látásmódját, továbbá megerősíthetné az LMBTdiákokat társadalmi létezésükben (Takács, 2007). Figyelemre méltó, hogy egy svéd LMBT-ifjúsági szervezet el tudta érni, hogy revideálják a biológiatankönyveket, „hogy van-e bennük szó LMBT-témákról, és ha igen, »helyes-e« a közölt tartalom”. Amely könyv nem felelt meg, azt kivonták a használatból. A projektnek akkora hatása volt, hogy más tantárgyak tekintetében is elkezdték a felülvizsgálatot (Takács, 2007. 81. o.).

\section{Összegzés}

Írásomban a transzneműségre mint identitásfejlődési kérdésre igyekeztem tekinteni. Ennek legfőbb tanulsága, hogy a transznemüség mint nemi identitás, független a szexuális orientációtól, alapvetően az egyén önmagáról alkotott képéről szól, és nem arról, hogy kihez vonzódik. Az egyén fejlődése szempontjából több identitásfejlődési elméletet vázoltam, amelyek a transznemüek önképének fejlődésére érvényesek lehetnek. 
Jelenleg a fejlődéslélektanban az egész életen át tartó fejlődés, változás modelljei tűnnek legelfogadhatóbbnak. Az identitás fejlődésének tárgykörében ez azt jelenti, hogy az ember életében vannak olyan események, amelyek mentén időnként újra és újraformálja önmagáról alkotott képét. A nemi identitás az identitás részterülete, amely bizonyos időszakokban jobban előtérbe kerül, fontosabb az egyén számára, mint más területek (munka, család, hobbi, egyéb betöltött szerepek). Ilyen, a nemi identitás szempontjából kiemelt időszak a kisgyermekkor (nemi konstancia kialakulása, nemi szerepek, környezet elvárásainak elsajátítása), és a serdülőkor (testi változások, első erotikus kapcsolat, nemi szereppróbálgatások). Transzneműek esetén meghatározó a másság felismerése, mibenlétének meghatározása, a coming out időszaka, valamint, amennyiben vállalják, a mütét körüli időszak.

A szülők szempontjából is vizsgálható a transznemüség kérdése: mi a teendő, ha a gyermek kilóg a neki szánt szexuális skatulyából, nem tud azonosulni az elvárt nemi szerepekkel a nemi identitás és/vagy a szexuális orientáció területén? Milyen lehetőségeik vannak, hogyan neveljék a gyermeküket az LMBTQ-gyermekek szülei? És mi a helyzet, ha a szülők tartoznak az LMBTQ-csoportba, és gyermekük ezzel összefüggésben küzd identitás problémával? Ilyen kérdésekre általában esettanulmányok, vagy kvalitatív vizsgálatok próbálnak választ keresni, támpontul szolgálni. A legjobb tanács, hogy engedjük a gyermeket, hogy megismerhesse, kifejezhesse önmagát úgy, ahogy szeretné, fogadjuk el, szeressük, és készítsük fel a nehézségekre, amelyek várnak rá. Szülőként pedig készüljünk fel, hogy önmagunkra, párkapcsolatunkra, és gyermekünkkel való viszonyunkra is friss szemmel tudjunk tekinteni. Legyünk nyitottak önmagunk és mások felé.

A pedagógusok a gyermekek szocializációs közegére vannak rendkívül nagy hatással. Az oktatási intézményekben tölti ugyanis a gyermek az ideje nagy részét óvodás korától középiskoláig. A szülők mellett a pedagógus az, aki elsősorban támogatást, biztonságot, segítséget nyújthat a gyermeknek megtalálni a számára kényelmes önkifejezés és nemi szerepviselkedés formáit, különösen az identitásformálódás szempontjából érzékenyebb életkorokban. A nemsemleges környezet segíthet a gyermeknek megtalálni a számára legmegfelelőbb tevékenységeket. A nemi diszfóriából eredő feszültség csökkentésére megoldás lehet a gyermek szociális nemváltása: a társas környezet (család, barátok, oktatási, és esetleg egészségügyi intézmény) kezelje a személyt vágyott nemének megfelelően.

A tanár a téma edukatív célú említésével, toleráns hozzáállás modellezésével segítheti a kortársak elfogadását az érintett gyermek irányában, föleg abban az időszakban, amikor a fiú-lány különbségek jelentősebbé válnak (serdülőkor eleje).

Az egyénnel foglalkozva a pedagógus - a szülökkel és az iskolapszichológussal karöltve - segíthet a nemi diszfóriából, bizonytalanságból fakadó stressz és negatív érzelmek csökkentésében, az asszertivitás (önérvényesítés mások érdekeinek sértése nélkül) fejlesztésében. Sokszor a bizonytalanság, fokozott stressz miatt magatartás- vagy tanulási zavar jelentkezik a gyermeknél, és a különféle szakemberek erre fókuszálnak, a háttértényezőkre kevesebb figyelem jut. Ilyen állapotban a gyermek halmozottan hátrányos lehet, vagy azzá válhat, föleg, ha az őt ért atrocitások következtében felhagy tanulmányaival.

Amennyiben a gyermek úgy kerül az oktatási intézménybe, hogy viselkedése alapján kilóg a neki szánt nemi kategória kereteiből, fontos tisztázni a szabályokat, kereteket gyakorlati szempontból (pl. hogyan szólítsák a gyermeket, melyik toalettet, öltözőt használja a diák, milyen mértékü öltözködésbeli eltérés elfogadható a szülő, a gyermek, az óvoda/iskola számára).

Több kutatás eredményei alapján elmondható, hogy mind diák, mind pedagógusi oldalról igény van rá, hogy kifejezetten előkerüljön az LMBTQ-téma az oktatásban, ne 
csak érintőlegesen, például irodalom- vagy biológiaórán. A nemi identitás és a szexuális orientáció kérdéskörét kényes témának ítélik, amely könnyen gerjeszt vitákat. Ezzel párhuzamosan tehát a pedagógusok önismerete, határozottsága, moderálási készsége is fejlesztendő, hogy biztonsággal kezelni tudják a konfliktusos, érzelemtelített helyzeteket (Takács, 2007; Mészáros, 2011). LMBTQ-témájú érzékenyítő iskolai programokhoz, pedagógusok továbbképzéséhez segítséget nyújthatnak az LMBTQszervezetek, például a Labrisz Leszbikus Egyesület, a Háttér Társaság, a Budapest Pride vagy a Transvanilla Transznemü Egyesület.

\section{Felhasznált irodalom}

Béres-Deák Rita (2010): „Anyu, Tina a szerelmed?” Gyermeket nevelő azonos nemű párok és az identitás vállalása. Thalassa, 21. 4. sz., 85-97.

Cass, V. C. (1979): Homosexuality Identity Formation: A Theoretical Model. Journal of Homosexuality, 4. 3. sz., 219-235.

Cohen-Kettenis, P. T. és Gooren, L. J. G. (1999): Transsexualism: A review of etiology, diagnosis and treatment. Journal of Psychosomatic Research, 46. 4. sz., 315-333.

Colapinto, J. (2000): As Nature Made Him: The Boy Who Was Raised As A Girl. HarperCollins Publishers, New York.

Collin, L., Reisner, S. L., Tangpricha, V. és Goodman, M. (2016): Prevalence of Transgender Depends on the "Case" Definition: A Systematic Review. The Journal of Sexual Medicine, 13. 4. sz., 613-626.

Dillon, F. R., Worthington, R. L. és Moradi, B. (2011): Sexual Identity as a Universal Process. In: Schwartz, S. J., Luyckx, K., Vignoles, V. L., (Eds.) Handbook of Identity Theory and Research, Springer, New York - Dordrecht - Heidelberg - London, 649-670.

Egan, S. K., Perry, D. G. (2001): Gender Identity: A Multidimensional Analysis With Implications for Psychosocial Adjustment. Developmental Psychology, 37. 4. sz., 451-463.

Fassinger, R. E. és Arseneau, J. R. (2007): „l'd Rather Get Wet Than Be Under That Umbrella”: Differentiating the Experiences and Identities of Lesbian, Gay, Bisexual, and Transgender People. In Bieschke, Kathleen J.; Perez, Ruperto M. és DeBord, Kurt A. (szerk.) Handbook of counseling and psychotherapy with lesbian, gay, bisexual, and transgender clients (2nd ed.), American Psychological Association, Washington, DC. 19-49.

Gagné, P., Tewksbury, R. és McGaughey, D. (1997): Coming out and crossing over. Identity Formation and Proclamation in a Transgender Community. Gender \& Society, 11. 4. sz., 478-508.

Jagose, A. (2003): Bevezetés a queer-elméletbe, Új Mandátum Könyvkiadó, Budapest.

Lev, A. I. (2004): Transgender emergence: Therapeutic guidelines for working with gendervariant people and their families. The Haworth Clinical Practice Press, New York, NY.

Lev, A. I. (2010): How Queer! The Development of Gender Identity and Sexual Orientation in LGBTQ-Headed Families. Family Process, 49. 3. sz., 268-290.

Mészáros György (2011): Tanári szerepvállalás a homofóbia elleni küzdelemben: pedagógushallgatók és LMBT emberek értelmezései. In: Takács Judit (szerk.) Homofóbia Magyarországon. L'Harmattan Kiadó, Budapest, 175-188.

Szilágyi Vilmos (szerk.) (é.n.): Nemiség: szervek és funkciók. (E. J. Haeberle e-learning kurzusa alapján). http://mek.oszk.hu/03600/03622/03622.pdf Letöltve: 2016.08.03.

Takács Judit (2006, szerk.): A lélek mütétei. Új Mandátum Könyvkiadó, Budapest.

Takács Judit (2007): Elöítélet és megkülönböztetés az iskolában. Educatio, 16. 1. sz., 67-83.

Transvanilla Transznemü Egyesület: http://transvanilla.hu/szotar Letöltve: 2016.03.01.

Transvanilla Transznemü Egyesület hírei: http://transvanilla.hu/hirek/dania-nem-var-a-who-raes-torli-a-transznemuseget-a-mentalis-betegsegek-listajarol Letöltve: 2016.05.18.

Vanderburgh, R. (2009): Appropriate Therapeutic Care for Families with Pre-Pubescent Transgender/Gender-Dissonant Children. Child and Adolescent Social Work Journal, 26.

2. sz., 135-154. 